Research Article

\title{
Enhancing the Phytoremediation of Hydrocarbon-Contaminated Soils in the Sudd Wetlands, South Sudan, Using Organic Manure
}

\author{
J. A. Ruley $\mathbb{D}^{1,2}$ A. Amoding, ${ }^{1}$ J. B. Tumuhairwe, ${ }^{1}$ T. A. Basamba, ${ }^{1}$ E. Opolot, ${ }^{1}$ \\ and H. Oryem-Origa ${ }^{3}$ \\ ${ }^{1}$ Department of Agricultural Production, Makerere University, P.O. Box 7062, Kampala, Uganda \\ ${ }^{2}$ Department of Agricultural Sciences, University of Juba, P.O. Box 82, Juba, South Sudan \\ ${ }^{3}$ Department of Natural Sciences, Makerere University, P.O. Box 7062, Kampala, Uganda \\ Correspondence should be addressed to J. A. Ruley; janenajeb@yahoo.com
}

Received 25 August 2019; Revised 18 December 2019; Accepted 6 February 2020; Published 11 March 2020

Academic Editor: Claudio Cocozza

Copyright (c) 2020 J. A. Ruley et al. This is an open access article distributed under the Creative Commons Attribution License, which permits unrestricted use, distribution, and reproduction in any medium, provided the original work is properly cited.

Phytoremediation of hydrocarbon-contaminated soils is a challenging process. In an effort to enhance phytoremediation, soil was artificially contaminated with known concentration of light crude oil containing Total petroleum hydrocarbon (TPH) at a concentration of $75 \mathrm{gkg}^{-1}$ soil. The contaminated soil was subjected to phytoremediation trial using four plant species (Oryza longistaminata, Sorghum arundinaceum, Tithonia diversifolia, and Hyparrhenia rufa) plus no plant used as control for natural attenuation. These phytoremediators were amended with concentrations ( 0,5 and $10 \mathrm{gkg}^{-1}$ soil) of organic manure (cow dung). Results at 120 days after planting, showed that application of manure at concentrations of 5 and $10 \mathrm{gkg}^{-1}$ soil combined with an efficient phytoremediator can significantly enhance reduction of TPH compared to natural attenuation or use of either manure or a phytoremediator alone $(p<0.05)$. The study also showed that a treatment combination of manure $5 \mathrm{gkg}^{-1}$ soil, with a phytoremediator gives a similar mean percentage reduction of TPH as manure $10 \mathrm{gkg}^{-1}$ soil $(p>0.05)$. Therefore, the study concludes that use of phytoremediators and manure $5 \mathrm{gkg}^{-1}$ soil could promote the restoration of TPH contaminated-soils in the Sudd region of South Sudan.

\section{Introduction}

Crude oil activities often lead to changes in the functioning of the soil ecosystem $[1,2]$. The crude oil products contaminate soil leading to deficiency of the much needed nutrients for normal functioning of plants [1, 3]. Studies such as $[3,4]$ have provided proof that crude oil contaminated soils have less content of nitrogen and phosphorus. Besides, the water repellant properties interrupt water infiltration into the soil [5], leading to water and nutrient deficiencies. These adversely affect plant growth and microbial populations such that where oil toxicity persists, and the soil becomes unsuitable for plant growth [4].

Over the years, in oil rich and exploiting countries, efforts have increasingly been taken to remediate contaminated sites [6]. Different approaches; physical, chemical, and biological have been undertaken. However, some of these are expensive while others have harmed the environment, particularly soil health and human livelihoods $[3,7,8]$. For example, excavation (physical approach) has logistics and transport constraints [9-12] while incineration (chemical approach) adds greenhouse gases in the atmosphere leading to global warming. This leaves use of biological approaches such as phytoremediation as the safest, feasible, and desirable [13]. Phytoremediation uses plants and microbes [13]. However, as indicated earlier, contaminated soils have deficient nutrients. To correct this defect, addition of supplementary nutrients such as organic manure is necessary $[14,15]$.

The use of organic manure is an environmentally safer option because it releases nutrients at a slower rate and as well act as a soil conditioner $[4,8,16]$. Also, organic manure contains nitrogen, magnesium, sulphur, phosphorus, and potassium that support plant growth [17-20]. Organic manure improves soil physical and chemical conditions and 
further maintains an adequate supply of soil organic matter with high microbial loads [4]. This enables faster degradation of hydrocarbon contaminants $[8,16]$. Evidence is provided by Kaimi et al. [21] in their study of rye grass, that addition of compost manure to the soil increases the rate of removal of Petroleum Hydrocarbons (PHCs) while Obasi et al. [22] reported removal of $60-65 \%$ of hydrocarbon from soils treated with manure and municipal biowaste compost. Different from these, this study was on biostimulation of phytoremediators using cow dung due to its prevalence in different environments making it almost cost free [23]. In South Sudan, cow dung is locally available owing to large numbers of cattle. According to Catley [24]; an average household in South Sudan owns four cows, Sudd region inclusive.

South Sudan is the third largest oil producing country in Africa after Nigeria and Angola [25]. Crude oil activities in the Sudd region of South Sudan have affected underground herbs and shrubs and as well, destroyed microbial organisms [26-29]. These environmental hazards are expected to worsen with continued crude oil drilling activities in the region [28]. Hence, biostimulation of crude oil contaminated soil in the Sudd with cow dung is necessary, given its availability. The usefulness of cow dung and other biostimulants have been previously reported. In Nigeria, Essien et al. [30] using Eleusine indica established that augmenting crude oil polluted soils with cow dung enhances its remediation potential leading to restoration of polluted soils. Njoku et al. [31] found the same effect using Glycine max; Isaac [32] used Panicum maximum and Talinum triangulare; and Oyedele and Amoo [33] confirmed similar results using Maize plant while Omara et al. [34] used Sorghum Bicolor L. (Moench) in petroleum adulterated soils from an automobile repair workshop in Kampala city, Uganda.

The Sudd Region, South Sudan, has a double advantage for benefiting from this innovation, given the prevalence of cow dung [24], and abundance of excellent phytoremediators. Ruley et al. [35] established Oryza longistaminata, Sorghum arundinaceum, Tithonia diversifolia, and Hyparrhenia rufa as very important phytoremediators in the Sudd wetland. Also, an earlier study by Ruley et al. [28] established their abundance in region. In the 2019 study, Ruley and colleagues observed that these plant species reduced TPH in the contaminated soil by over $50 \%$ in the concentration TPH $75 \mathrm{gkg}^{-1}$ soil. Despite the excellence of these phytoremediators (such as $H$. rufa) confirmed by Ruley et al. [35] and the availability of cow dung in the region, no studies have assessed the potential of augmenting crude oil contaminated soils planted with the abovementioned phytoremediators with cow dung. Thus, the objective of this study was to determine the optimal concentration of cow dung capable of enhancing the phytoremediation of hydrocarbon contaminated soils by these phytoremediators in the Sudd region, South Sudan.

\section{Material and Methods}

2.1. Experimental Site and Design. The study was carried out in a greenhouse subjected to the following treatments; concentrations of cow dung $\left(0,5\right.$, and $10 \mathrm{gkg}^{-1}$ soil) and TPH concentrations of 0 and $75 \mathrm{gkg}^{-1}$ soil. The crude oil (light) used in the experiment was obtained from Dar Petroleum Operating Company Ltd., Operation Base Camp in Paloch, South Sudan. Seeds of four efficient phytoremediators were obtained from the Sudd region of South Sudan (Table 1). To remove TPH under the natural attenuation process, no plants were used (i.e., control). The four selected phytoremediators have high potential for removal of over $50 \% \mathrm{TPH}$ in contaminated soils assessed in the Sudd region (Table 1 ).

The trial was conducted in a Completely Randomized Design (CRD) with 30 treatments and replicated three times using Genstat. This gave 90 treatment pots $(5$ plants $\times 2 \mathrm{TPH}$ concentrations $\times 3$ concentrations of cow dung $\times 3$ replicates).

Partially decomposed cow dung with a nutrient composition ratio of $1.7: 0.6: 0.8(\mathrm{NPK})$ was used for the experiment while the soil was collected from uncontaminated natural land in the Sudd region as composite top soil samples at a depth of $0-30 \mathrm{~cm}$. The Sudd region is located within latitudes $6030^{\prime}-9030^{\prime} \mathrm{N}$ and longitudes $30010^{\prime}-310$ $45^{\prime} \mathrm{E}$, with an elevation of $320 \mathrm{~m}$ above sea level. Table 2 shows the characteristics of the soil sample used.

The soil samples were air-dried and sieved to remove debris and then apportioned into $5 \mathrm{~kg}$ per pot for the subsequent experiments. The soil, cow dung, and crude oil were thoroughly mixed on a metallic sheet and then returned into 8-litre pots. The polypropylene pots were perforated at the base to allow drainage and aeration. They were labeled with respective treatments and left to stand for one week before planting. To cater for TPH drainage from the pots, a lid was placed under each perforated pot to collect the leached water. The water was reused to irrigate the pots which controlled TPH loss. Also, periodically, the pot lids were rinsed with deionized distilled water and the resulting wash solution was poured back into the respective pots, further minimizing any losses of TPH.

The seed viability was determined through floatation technique with those remaining at the bottom of the water considered potentially viable. Ten seeds of each plant were sown in each pot and on establishment; the seedlings were thinned to three plants per pot and irrigated with deionized water up to field capacity at two-day intervals up to the end of the experiment (four months after planting). Any weeds that emerged from some of the pots were hand-pulled. Also, the whiteflies were controlled by foliar sprays of Dimethoate $(0.05 \%)$.

2.2. Data Collection. Data on plant height, total dry matter, and percentage reduction of TPH were collected once at 120 days after planting (DAP). For plant height measurements, the abovementioned ground parts (shoots) of the plants were cut off at the soil surface, followed by destruction of the pots. The carefully crushed pots were shaken into a vat to carefully collect the roots which were washed under running tap water and air-dried to remove surface water. The fresh weights of the partitioned plants 
TABLE 1: Sudd region phytoremediators of petroleum hydrocarbon.

\begin{tabular}{lcc}
\hline $\begin{array}{l}\text { Phytoremediator } \\
\text { Common/local name }\end{array}$ & Percentage reduction of TPH from concentration of $75 \mathrm{gkg}^{-1}$ soil \\
\hline Thatching grass & Syparrhenia rufa & 74.40 \\
Wild rice & Oryza longistaminata & 56.17 \\
False sunflower & Tithonia diversifolia & 55.92 \\
Sudan grass & Sorghum arundinaceum & 50.12 \\
No plant (control) & No plant (control) & 14.80 \\
\hline
\end{tabular}

Source: Ruley et al. [35].

TABLE 2: Physical and chemical characteristics of the soil used for the greenhouse experiment.

\begin{tabular}{|c|c|c|c|c|c|c|c|c|c|c|c|c|c|}
\hline $\begin{array}{l}\text { Parameters } \\
\text { Units }\end{array}$ & \multicolumn{4}{|c|}{$(\%)$} & $\begin{array}{c}\mathrm{pH} \\
\left(\mathrm{H}_{2} \mathrm{O}\right)\end{array}$ & $\begin{array}{c}\mathrm{P} \\
\mathrm{mg} / \mathrm{kg}\end{array}$ & $\mathrm{TN}$ & SOC & \multicolumn{4}{|c|}{$(\mathrm{cmol}(+) / \mathrm{kg}$ soil $)$} & $\mathrm{Ca}$ \\
\hline Test value & 24.2 & 61.3 & 14.5 & Clay & 6.71 & 15.64 & 0.27 & 5.01 & 26.6 & 1.69 & 0.94 & 1.25 & 9.92 \\
\hline Critical value $\mathrm{a}^{\mathrm{a}}$ & - & - & - & - & 5.5 & 15 & 0.2 & 3 & 25 & 0.5 & $<1.0$ & 0.6 & 10 \\
\hline
\end{tabular}

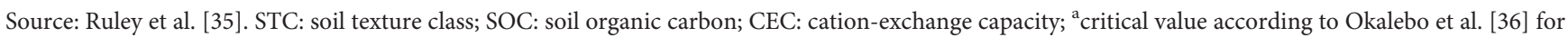
most crops in East Africa.

were measured. Each of the plant parts was oven-dried at $65^{\circ} \mathrm{C}$ to constant weight in order to determine the plant total dry matter yield. After removing the roots, the soil from each pot (planted and unplanted) was first homogenized before being sampled and stored at $-4^{\circ} \mathrm{C}$ until further processing and analysis of TPH. The TPH concentrations were determined by extracting $5 \mathrm{~g}$ of soil samples with $10 \mathrm{~mL}$ dichloromethane (DCM). The extract was then filtered, evaporated, and passed through silica gel before injection to gas chromatograph. The Varian CP3800 gas chromatograph used was equipped with a flame ionization detector (GC-FID) and split less injector in DB5 capillary column of $100 \%$ polydimethylsiloxane ( $30 \mathrm{~m} \times 0.25 \mathrm{~mm}$ I.D $\times 0.25 \mu \mathrm{m}$ film thickness). The carrier gas was helium at a flowing rate of $1.5 \mathrm{~mL} / \mathrm{min}$ and the injector and detector temperature of $300^{\circ} \mathrm{C}$ and $320^{\circ} \mathrm{C}$. The column head pressure was $175 \mathrm{kPa}$. Oven temperature was programmed at an initial temperature of $35^{\circ} \mathrm{C}$, initial hold time of $8^{\circ} \mathrm{C} / \mathrm{min}$, temperature rate of $27^{\circ} \mathrm{C} / \mathrm{min}$ up to $100^{\circ} \mathrm{C}$, temperature rate of $35^{\circ} \mathrm{C} / \mathrm{min}$ up to $300^{\circ} \mathrm{C}$, and a final hold time of $5 \mathrm{~min}$. The calibration of GC-FID was performed with the following standards: $2,10,25$, and $1000 \mathrm{mg} / \mathrm{L}$. TPH was calculated using a programmed integration event timetable. The United States Environmental Protection Agency (USEPA) SW-846 series, method $9071 \mathrm{Bd} 5$ was used to compute TPH concentrations. The percentage of TPH degradation was subtracted from the final gas chromatograph results of the soil sample after harvesting and the output was multiplied by $100 \%$. The quality of the batch of soil extracts used was ensured by including blank samples to improve the evaluation of data. The blank samples were prepared using hydrocarbon free soil and then processed using the same extraction technique with known amounts of normal alkanes to check percent recoveries. The hydrocarbon components were analyzed by gas chromatography techniques. The data were displayed as Total Ion Chromatogram (TIC). The information obtained from TIC was used to identify or classify individual components contained in the sample.
The reference material was obtained from Petroleum Laboratories, Research and Studies of Sudanese Petroleum Corporation (SPC).

2.3. Statistical Analyses. The data for plant height, total dry weight, and TPH percentage reduction in the soil were analyzed using Genstat to generate treatment means using Fisher's Least Significant Difference (LSD) test at $5 \%$ level of significance.

\section{Results}

3.1. Plant Height and Dry Weight. The mean plant heights for the control with cow dung manure treatments were higher than that of all treatment combinations with TPH concentration $75 \mathrm{gkg}^{-1}$ soil. Generally, and as would be expected, the shortest plants were observed at treatments where there was no manure applied yet the soil was contaminated with TPH concentration $75 \mathrm{gkg}^{-1}$ soil (Table 3). Plant growth (in terms of height) was noticeably improved in treatments containing combinations of TPH concentration $75 \mathrm{gkg}^{-1}$ soil with either

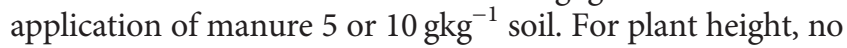
significant difference was observed between treatment combinations of manure 5 and $10 \mathrm{gkg}^{-1}$ soil with TPH concentration $75 \mathrm{gkg}^{-1}$ soil $(p>0.05)$ (Table 3$)$.

The plants in the control yielded more dry weight content than in all treatment combinations with TPH concentration $75 \mathrm{gkg}^{-1}$ soil. Generally, and as would be expected, the light weight plants were observed in treatments where there was no manure applied yet the soil was contaminated with TPH concentration $75 \mathrm{gkg}^{-1}$ soil (Table 4). There were more pronounced reductions in the total plant dry weight in all the four phytoremediators in treatment combination of $75 \mathrm{gkg}^{-1}$ soil manure and TPH concentrations, respectively. This improved with the addition of manure 5 and $10 \mathrm{gkg}^{-1}$ soil to $\mathrm{TPH}$-contaminated soils ( $75 \mathrm{gkg}^{-1}$ soil) leading to increased biomass yield for all the plant species studied. However, a least significant difference 
TABLE 3: Treatments effect on the height of four phytoremediators.

\begin{tabular}{|c|c|c|c|c|c|c|}
\hline \multirow[b]{2}{*}{$\begin{array}{l}\text { Phytoremediators (plant } \\
\text { species) }\end{array}$} & \multicolumn{3}{|c|}{ TPH, $0 \mathrm{gkg}^{-1}$ soil } & \multicolumn{3}{|c|}{ TPH, $75 \mathrm{gkg}^{-1}$ soil } \\
\hline & $\begin{array}{c}\mathrm{M}, \underset{\mathrm{gkg}}{ } \mathbf{c m} \\
\mathrm{cm}\end{array}$ & $\begin{array}{l}\mathrm{M}, \begin{array}{l}5 \mathrm{gkg}^{-1} \\
\text { soil }\end{array} \\
\end{array}$ & $\begin{array}{l}\mathrm{M}, 10 \mathrm{gkg}^{-1} \\
\text { soil }\end{array}$ & $\begin{array}{c}\mathrm{M}, \underset{\mathrm{gkg}}{0-1} \text { soil } \\
\mathrm{cm}\end{array}$ & $\begin{array}{l}\text { M, } \\
\text { soil } \\
\text { gkg }\end{array}$ & $\begin{array}{l}\mathrm{M}, 10 \mathrm{gkg}^{-1} \\
\text { soil }\end{array}$ \\
\hline H. rufa & 160 & 163 & 164.4 & 129 & 141 & 142 \\
\hline O. longistaminata & 97.1 & 102.0 & 102.2 & 40.1 & 60.0 & 62.7 \\
\hline T. diversifolia & 116.1 & 121.2 & 123.6 & 90.3 & 107.2 & 109.4 \\
\hline S. arundinaceum & 130.1 & 134.3 & 135.9 & 70.5 & 100.5 & 103.3 \\
\hline CV \% & \multicolumn{6}{|c|}{1.9} \\
\hline LSD (5\%) & \multicolumn{6}{|c|}{3.08} \\
\hline
\end{tabular}

$\mathrm{TPH}=$ total petroleum hydrocarbon; $\mathrm{M}=$ manure .

TABLE 4: Treatments effect on the total plant dry weight of four phytoremediators.

\begin{tabular}{|c|c|c|c|c|c|c|}
\hline \multirow[b]{2}{*}{$\begin{array}{l}\text { Phytoremediators } \\
\text { (plant species) }\end{array}$} & \multicolumn{3}{|c|}{ TPH, $0 \mathrm{gkg}^{-1}$ soil } & \multicolumn{3}{|c|}{ TPH, $75 \mathrm{gkg}^{-1}$ soil } \\
\hline & $\begin{array}{l}\mathrm{M}, 0 \mathrm{gkg}^{-1} \\
\text { soil (g) }\end{array}$ & $\begin{array}{l}\mathrm{M}, \begin{array}{l}5 \mathrm{gkg}^{-1} \\
\text { soil }\end{array} \\
\end{array}$ & $\begin{array}{l}\mathrm{M}, 10 \mathrm{gkg}^{-1} \\
\text { soil }\end{array}$ & $\begin{array}{c}\mathrm{M}, 0 \mathrm{gkg}^{-1} \text { soil } \\
(\mathrm{g})\end{array}$ & $\mathrm{M}, 5 \mathrm{gkg}^{-1}$ soil & $\begin{array}{l}\mathrm{M}, \begin{array}{c}10 \mathrm{gkg}^{-1} \\
\text { soil }\end{array} \\
\end{array}$ \\
\hline H. rufa & 13.5 & 15.1 & 15.9 & 7.1 & 10.1 & 10.9 \\
\hline O. longistaminata & 7.8 & 8.2 & 9.2 & 4.2 & 6.1 & 6.7 \\
\hline T. diversifolia & 12.1 & 15.2 & 16.5 & 9.0 & 11.3 & 12.0 \\
\hline S. arundinaceum & 15.5 & 20.2 & 20.9 & 10.1 & 12.1 & 13.2 \\
\hline $\mathrm{CV} \%$ & & & & 2.8 & & \\
\hline LSD (5\%) & & & & 0.9 & & \\
\hline
\end{tabular}

$\mathrm{TPH}=$ total petroleum hydrocarbon; $\mathrm{M}=$ manure .

between treatment combinations of manure 5 and manure $10 \mathrm{gkg}^{-1}$ soil with TPH concentration $75 \mathrm{gkg}^{-1}$ soil was observed in $S$. arundinaceum $(p<0.05)$ while no significant differences were observed in H. rufa, O. Longistaminata, and T. diversifolia $(p>0.05)$ (Table 4$)$.

\subsection{Effect of Manure on Phytoremediation of Hydrocarbon} Contaminated Soil. The mean percentage reduction of TPH in the four phytoremediators with manure treatments was measured at 120 days after planting (Figure 1). The reductions in the control (i.e., soils with no phytoremediator planted) were lower than those in treatments with 0,5 , and $10 \mathrm{gkg}^{-1}$ soil manure concentrations. Thus, it is evident that the presence of treatments of manure 5 and $10 \mathrm{gkg}^{-1}$ soil improved the percentage reduction of TPH compared to treatments of phytoremediators without manure. No significant differences $(p>0.05)$ in mean percentage reduction of $\mathrm{TPH}$ were observed between the manure 5 and $10 \mathrm{gkg}^{-1}$ soil treatments for all the four plant species (Figure 1).

The total ion chromatograms (TICs) of the hydrocarbon fractions from the control and treatments are shown in Figure 2. The chromatograms gave qualitative and semiquantitative information on the changes in the composition of hydrocarbons in the samples. The compounds in the hydrocarbon fractions of the control ranged from n-C13 to $\mathrm{n}-\mathrm{C} 40$ and maximizing at $\mathrm{n}-\mathrm{C} 26$. In the treatment with plant alone, it ranged from n-C20 to n-C40. In both treatments of plant, manure 5 and $10 \mathrm{gkg}^{-1}$ soil, the compounds ranged from n-C29 to n-C32.

\section{Discussion}

Biostimulation of hydrocarbon contaminated soils with cow dung in the Sudd wetland holds potential of restoring the hydrocarbon contaminated soils through bioremediation. This is boosted by the abundance of O. longistaminata, S. arundinaceum, T. diversifolia, and $H$. rufa plant species as naturally existing phytoremediators [28], although their growth is inhibited by high concentration of TPH in the soils. In this study, in the treatments without manure, plant species grew short and recorded light dry weight content compared to the control and treatments with manure. The inhibition is attributed to the unconducive conditions that are caused by crude oil contamination such as water repellency which causes reduced access to water and oxygen by the plants. This partly explains the plant shortness and lightness of the plant dry weight. On the other hand, the crude oil contaminants altered the soil physical properties such as permeability which affected the growth of plant species. The finding is supported by Akinwumi et al. [37] and Nazir [38] who unanimously observed that contamination of soil by crude oil alters the soil physical properties which affects the free flow of total organic carbon and soil mineral nutrients such as potassium, sulfate, phosphate, and nitrate of soil. More light is shed by Akubugwo et al. [39] and Wang et al. [40] that nutrient deficiencies inhibit the growth of plant species in hydrocarbon contaminated soils.

Though Ruley et al. [35] ascertained four plant species (O. longistaminata, S. arundinaceum, T. diversifolia, and $H$. rufa) as prominent phytoremediators, this study confirmed that augmentation with cow dung led to a marked improvement in the plant growth characteristics. There were least significant differences between treatments without manure and those with manure in terms of both plant height and dry weight $(p<0.05)$. The improvement in plant height and dry weight content is attributed to the restoration of lost nutrients by addition of cow dung since it contains high nutrient composition hence providing polluted soil with 


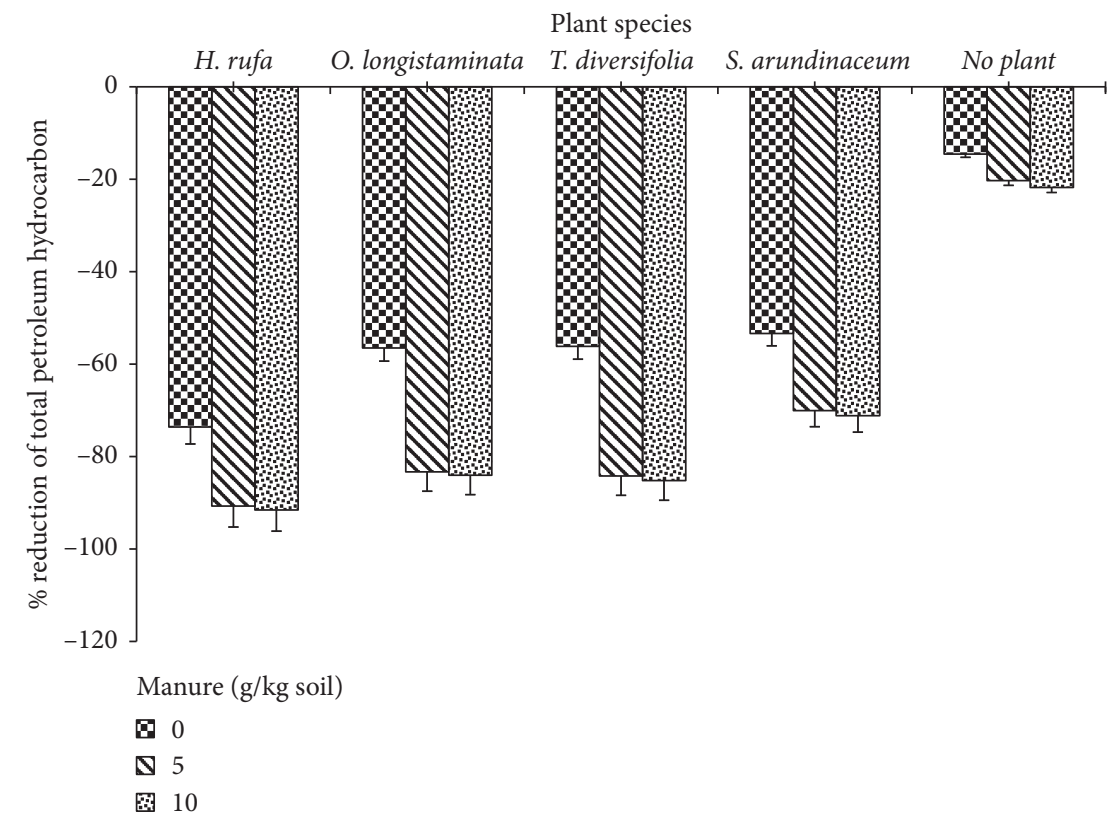

FIGURE 1: Effect of manure application on phytoremediation of hydrocarbon-contaminated soil; bars show the standard errors (SE) for mean percentage reduction of $\mathrm{TPH}, n=3$.

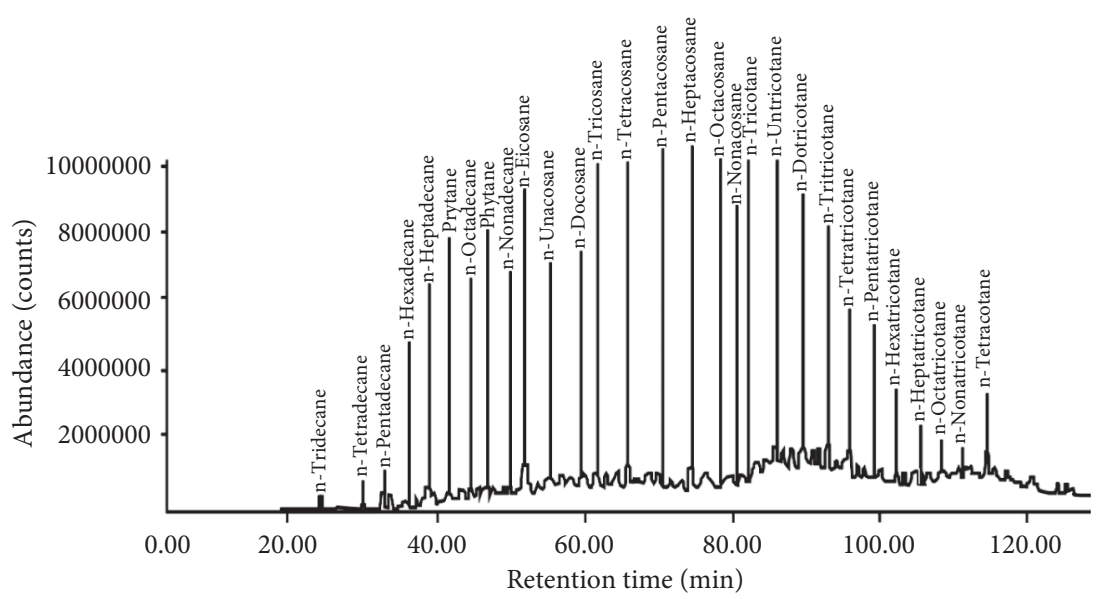

(a)

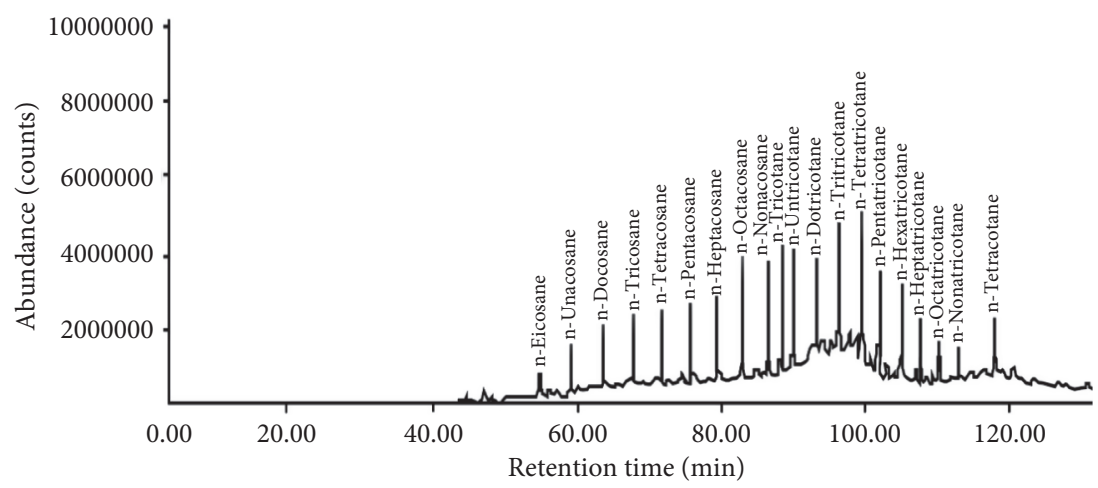

(b)

Figure 2: Continued. 


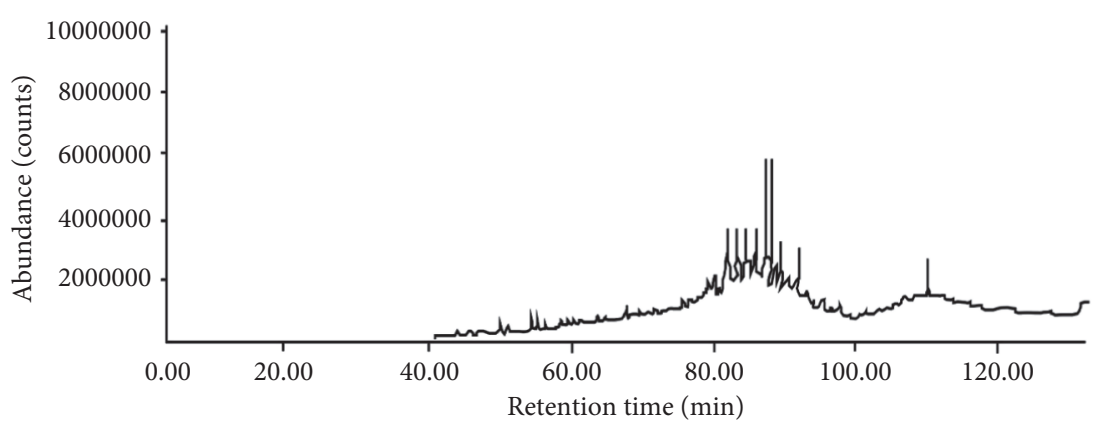

(c)

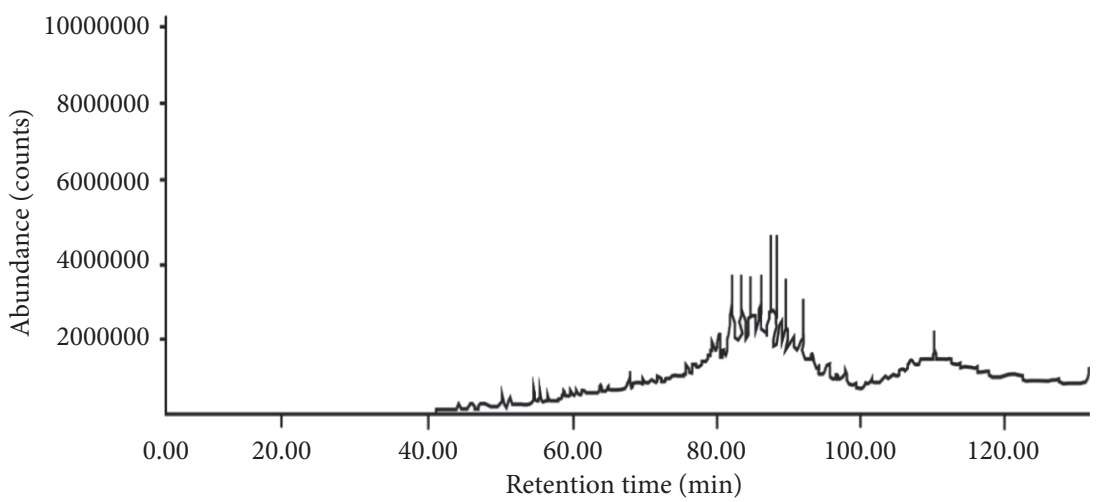

(d)

FIgURE 2: Total ion chromatograms (TIC) of the TPH extracts of the control and treatments during the bioremediation experiment after 120 days. (a) No treatment. (b) Treated with plants. (c) Treated with plant and manure $5 \mathrm{gkg}^{-1}$ soil. (d) Treated with plant and manure $10 \mathrm{gkg}{ }^{-1}$ soil.

nutrient elements. Also, cow dung is effective, economic, and ecofriendly and leads to complete mineralization of hydrocarbons [41] which enhances phytoremediation. Evidence of this effect is provided by the analyses based on TIC which showed a gradual decrease in the hydrocarbon compounds after 120 days implying that some of the compounds had been completely biodegraded and could not be observed in the chromatograms Basing on this finding, $O$. longistaminata, S. arundinaceum, T. diversifolia, and $H$. rufa become more viable phytoremediators when augmented with cow dung. This assertion rhymes Oyedele and Amoo [33] that addition of cow dung manure improves on the calcium, magnesium, phosphorus, potassium, and nitrogenous contents which are vital elements for better growth of plant species. Essien et al. [30] also observed that the ubiquitous nature of cow dung reduces the cost of using inorganic fertilizers which further reduces the cost of cleaning up crude oil contaminated soils.

In this study, there is a nonsignificant difference between use of manure $5 \mathrm{gkg}^{-1}$ soil and $10 \mathrm{gkg}^{-1}$ soil. The study recommends that any plans should settle for $5 \mathrm{gkg}^{-1}$ soil as the optimal amount. There is a high possibility that using $10 \mathrm{gkg}^{-1}$ soil could divert the attention of the any existing microbes from feeding on crude oil to feeding on nutrients in cow dung. This diversion slows down the process of phytoremediation as was observed in some studies such as Essien et al. [30] that excess application of cow dung has the potential of causing the existing microbes to abandon crude oil and turn to feeding on the nutrients provided by the cow dung.

\section{General Conclusion}

In different environments, petroleum and petroleum-derived products inhibit plant growth and development. TPH inhibits the normal functioning of plants by interfering with the processes of intake of water and minerals from the substrate. Also, it slows down and impedes a number of metabolic processes from taking place. Case in point, when oil penetrates seed coats, it causes death of the seed embryo. Although remediation of TPH contaminated soils is a challenging task, results of this study have revealed that biostimulating crude oil polluted soils with cow dung significantly enhances plant growth parameters. Consequently, this increases their efficiency as phytoremediators. This study has demonstrated that application of cow dung at concentrations of 5 and $10 \mathrm{gkg}^{-1}$ soil, combined with efficient phytoremediators can significantly enhance the reduction of TPH compared to natural attenuation or use of either manure or phytoremediators alone. Furthermore, this study has elucidated that a combination of organic manure $5 \mathrm{gkg}^{-1}$ soil with a phytoremediator yields the same mean percentage reduction of TPH as $10 \mathrm{gkg}^{-1}$ soil. This study concludes that cow dung manure improves the phytoremediation potential of plant species in the Sudd wetland, South Sudan, and recommends the use of a combination of phytoremediators and $5 \mathrm{gkg}^{-1}$ soil of cow dung as the best combination for enhancing the remediation. Use of cow dung proves cost-effective compared to other remediation techniques and provides an ideal solution to the government 
of South Sudan and its development partners for phytoremediation of TPH contaminated soils in and around the Sudd region. Facilitating conditions to support this strategy exist in the region such as the availability of high numbers of cattle, with an average of 4 heads per household. This presents potential opportunities for restoration of crude oil contaminated soils in the region at a low cost.

\section{Data Availability}

The data used to support the findings of this study are available on request from Jane Alexander Ruley (janenajeb@ yahoo.com; +256756352256)

\section{Conflicts of Interest}

The authors declare that they have no conflicts of interest.

\section{Acknowledgments}

The authors would like to thank NORAD for funding this study through the Sudd project (NORHED Project no. SSD13/0021) implemented by University of Juba, Makerere University, and the Norwegian University of Life Sciences. The authors also acknowledge the support of the Ministry of Petroleum and Gas, Dar Petroleum Company Ltd, Sudanese Petroleum Laboratories, for analysis of the soil samples.

\section{References}

[1] P. L. O’Brien, T. M. DeSutter, F. X. Casey, A. F. Wick, and E. Khan, "Evaluation of soil function following remediation of petroleum hydrocarbons. A review of current remediation techniques," Current Pollution Reports, vol. 3, no. 3, pp. 192-205, 2017.

[2] D. Włóka, M. Kacprzak, A. Grobelak, A. Grosser, and A. Napora, "The impact of PAHs contamination on the physicochemical properties and microbiological activity of industrial soils," Polycyclic Aromatic Compounds, vol. 35, no. 5, pp. 372-386, 2015.

[3] C. M. Morales-Bautista, R. H. Adams, J. R. Hernández-Barajas, C. E. Lobato-García, and J. G. Torres-Torres, "Characterization of fresh and weathered petroleum for potential impacts to soil fertility," International Journal of Environmental Science and Technology, vol. 13, no. 11, pp. 2689-2696, 2016.

[4] L. S. Khudur, D. B. Gleeson, M. H. Ryan et al., "Implications of co-contamination with aged heavy metals and total petroleum hydrocarbons on natural attenuation and ecotoxicity in Australian soils," Environmental Pollution, vol. 243, pp. 94102, 2018.

[5] R. H. Adams, F. J. G. Osorio, J. Z. Cruz et al., "Water repellency in oil contaminated sandy and clayey soils," International Journal of Environmental Science \& Technology, vol. 5, no. 4, pp. 445-454, 2008.

[6] B. Song, G. Zeng, J. Gong et al., "Evaluation methods for assessing effectiveness of in situ remediation of soil and sediment contaminated with organic pollutants and heavy metals," Environment International, vol. 105, pp. 43-55, 2017.

[7] G. Cheng, J. Niu, W. Guo, X. An, and L. Zhao, "Ecological and health risk-based characterization of agricultural soils contaminated with polycyclic aromatic hydrocarbons in the vicinity of a chemical plant in China," Chemosphere, vol. 163, pp. 461-470, 2016.

[8] F. Hussain, I. Hussain, A. H. A. Khan et al., "Combined application of biochar, compost, and bacterial consortia with Italian ryegrass enhanced phytoremediation of petroleum hydrocarbon contaminated soil," Environmental and Experimental Botany, vol. 153, pp. 80-88, 2018.

[9] J. D. Arthur and B. G. Casey, "Strategies for sustainable management of oil field wastes and wastewaters in shale resource plays," in shale resource plays, in. Proceedings of the Shale Energy Engineering Conference 2014, pp. 404-411, Shale Energy Engineering 2014: Technical Challenges, Environmental Issues and Public Policy, Pittsburgh, PA, USA, July 2014.

[10] M. Marinescu, A. Lacatusu, E. Gament, G. Plopeanu, V. Carabulea, and M. Marinescu, "A review of biological methods to remediate crude oil polluted soil," Annals of the University of Craiova-Agriculture, Montanology, Cadastre Series, vol. 46, no. 1, pp. 35-340, 2017.

[11] G. O. Oyetibo, K. Miyauchi, Y. Huang et al., "Biotechnological remedies for the estuarine environment polluted with heavy metals and persistent organic pollutants," International Biodeterioration and Biodegradation, vol. 199, pp. 614-625, 2016.

[12] S. Pal, F. Banat, A. Almansoori, and M. Abu Haija, "Review of technologies for biotreatment of refinery wastewaters: progress, challenges and future opportunities," Environmental Technology Reviews, vol. 5, no. 1, pp. 12-38, 2016.

[13] D. Okoro, P. O. Oviasogie, and F. E. Oviasogie, "Soil quality assessment 33 months after crude oil spillage and clean-up," Chemical Speciation \& Bioavailability, vol. 23, no. 1, pp. 1-6, 2011.

[14] D. Arezoo and P. Agamuthu, "Organic wastes to enhance phytotreatment of diesel-contaminated soil," Waste Management and Research, vol. 31, no. 11, pp. 1133-1139, 2013.

[15] R. Tahseen, M. Afzal, S. Iqbal et al., "Rhamnolipids and nutrients boost remediation of crude oil-contaminated soil by enhancing bacterial colonization and metabolic activities," International Biodeterioration \& Biodegradation, vol. 115, pp. 192-198, 2016.

[16] J. E. Vidonish, K. Zygourakis, C. A. Masiello, X. Gao, J. Mathieu, and P. J. J. Alvarez, "Pyrolytic treatment and fertility enhancement of soils contaminated with heavy hydrocarbons," Environmental Science \& Technology, vol. 50, no. 5, pp. 2498-2506, 2016.

[17] D. V. Adeyunloye, F. C. Adetuyi, F. A. Akyinyosoye, and M. O. Doyeni, "Microbial analysis of compost using cow dung as booster," Pakistan Journal of Nutrition, vol. 6, no. 5, pp. 506-510, 2007.

[18] P. Agamuthu, Y. S. Tan, and S. H. Fauziah, "Bioremediation of hydrocarbon contaminated soil using selected organic wastes," Procedia Environmental Sciences, vol. 18, pp. 694$702,2013$.

[19] C. Angela, C. I. Udebuani, H. Okoli, C. Nwigwe, and P. T. E. Ozoh, "The value of animal manure in the enhancement of bioremediation processes in petroleum hydrocarbon contaminated agricultural soils," Journal of Agricultural Technology, vol. 8, no. 6, pp. 1935-1952, 2012.

[20] V. Azadeh, P. Ebrahim, and H. M. B. Masoud, "Phytoremediation, a method for treatment of petroleum hydrocarbon contaminated soils," IJFAS Journal, vol. 2, no. 21, pp. 909-913, 2011.

[21] E. Kaimi, T. Mukaidani, S. Miyoshi, and M. Tamaki, "Ryegrass enhancement of biodegradation in diesel-contaminated soil," Environmental and Experimental Botany, vol. 55, no. 1, 2006. 
[22] N. A. Obasi, E. Eze, D. I. Anyanwu, and U. C. Okorie, "Effects of organic manures on the physico-chemical properties of crude oil polluted soils," African Journal of Biochemistry Research, vol. 7, no. 6, pp. 67-75, 2013.

[23] I. Okunwaye, I. Ogboghodo, S. Ewansiha, and O. E. Oriakpno, "Biostimulation potentials of cow dung on a crude oil polluted soil," International Journal of Plant \& Soil Science, vol. 27, no. 1, pp. 1-11, 2019.

[24] A. Catley, "Livestock and livelihoods in South Sudan," in Help Desk Report, Knowledge, Evidence and Leaning for Development, Development, DFID, London, UK, 2018.

[25] L. A. Patey, "Crude days ahead? Oil and the resource curse in Sudan," African Affairs, vol. 109, no. 437, pp. 617-636, 2010.

[26] E. L. L. Loro and Z. Lu, "The environmental and social impacts of oil production on melut basin South Sudan," The International Journal of Scientific and Research Publication, vol. 8, no. 10, pp. 197-207, 2018.

[27] H. Rueskamp, J. Ariki, K. Stieglitz, and C. Treskatis, "Effect of oil exploration and production on the salinity of a marginally permeable aquifer system in the Thar Jath-, Mala- and Unity Oilfields, Southern Sudan," Zentralblatt für Geologie und Paläontologie, Teil I, vol. 2014, no. 1, pp. 95-115, 2014.

[28] J. A. Ruley, A. Amoding, J. B. Tumuhairwe, T. Basamba, and H. Oryem-Origa, "Hydrocarbons in crude-oil production sites of Sudd-region South-Sudan: implication on soil fertility and plant species risk," International Journal of Current Research, vol. 9, no. 12, pp. 63070-63075, 2017.

[29] F. Pragst, K. Stieglitz, H. Runge et al., "High production of salinity in Oil fields, Southern Sudan," Zbl. Geol. Paläont. Teil I, Jg. Heft, vol. 1, pp. 95-115, 2016.

[30] E. Essien, M. Efeanacho, and G. Nwachukwu, "The impact of cow dung augmentation for remediation of crude oil polluted soil by eleusine indica," Journal of Applied Sciences and Environmental Management, vol. 19, no. 1, pp. 103-107, 2015.

[31] K. L. Njoku, M. O. Akinola, and B. O. Oboh, "Phytoremediation of crude oil polluted soil: effect of cow dung augmentation on the remediation of crude oil polluted soil by Glycine max," Journal of Applied Sciences Research, vol. 8, no. 1, pp. 277-282, 2012.

[32] U. A. Isaac, "Assessment of local tropical plants for phytoremediation of petroleum contaminated soil," Journal of Research in National Development, vol. 6, no. 1, 2008.

[33] A. O. Oyedele and I. A. Amoo, "Remediation of crude oil polluted soil using cow dung manure in relations to the growth of maize (Zea mays L.)," Canadian Open Agricultural and Soil Science Journal, vol. 1, no. 1, pp. 1-16, 2014.

[34] T. Omara, R. Kalukusu, E. Adupa, T. Owori, D. M. Kizza, and J. Obonge, "Potential of Sorghum bicolor L. (Moench) and the effect of enhancements in remediation of petroleum-vitiated soils of an automobile repair," 2019.

[35] J. A. Ruley, J. B. Tumuhairwe, A. Amoding, E. Opolot, H. Oryem-Origa, and T. Basamba, "Assessment of plants for phytoremediation of hydrocarbon-contaminated soils in the Sudd Wetland of South Sudan," Plant, Soil and Environment, vol. 65, no. 9, pp. 463-469, 2019.

[36] J. R. Okalebo, K. W. Gathua, and P. L. Woome, Laboratory Methods of Soil and Plant Analysis: A Working Manual, Sacred African Publishers, Nairobi, Kenya, 2nd edition, 2002.

[37] I. I. Akinwumi, D. Diwa, and N. Obianigwe, "Effects of crude oil contamination on the index properties, strength and permeability of lateritic clay," International Journal of Applied Sciences and Engineering Research, vol. 3, no. 4, pp. 816-824, 2014.
[38] A. K. Nazir, "Effect of motor oil contamination on geotechnical properties of over consolidated clay," Alexandria Engineering Journal, vol. 50, no. 4, pp. 331-335, 2011.

[39] E. I. Akubugwo, G. C. Ogbuji, C. G. Chinyere, and E. A. Ugbogu, "Physicochemical properties and enzymes activity studies in a refined oil contaminated soil in Isiukwuato, Abia State, Nigeria," Biokemistri, vol. 21, no. 2, 2009.

[40] Y. Wang, J. Feng, Q. Lin, X. Lyu, X. Wang, and G. Wang, "Effects of crude oil contamination on soil physical and chemical properties in Momoge wetland of China," Chinese Geographical Science, vol. 23, no. 6, pp. 708-715, 2013.

[41] T. M. Neethu, P. K. Dubey, A. R. Kaswala, and K. G. Patel, "Cow dung as a bioremediation agent to petroleum hydrocarbon contaminated agricultural soils," Current Journal of Applied Science and Technology, vol. 38, no. 6, pp. 1-9, 2019. 